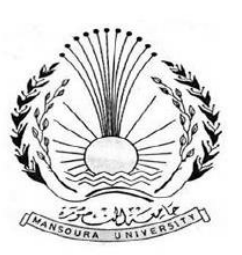

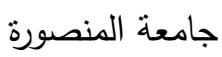

كلية السياحة والفنادق

Classification of Monkey's Roles

Relating to the Daily Life Scenes in

Ancient Egypt

Engy El-Kilany \& Maged Rady

Faculty of Tourism and Hotels

Minia University-Egypt 


\title{
Classification of Monkey's Roles Relating to the Daily Life Scenes in Ancient Egypt
}

\begin{abstract}
Animal depictions are abundant in visual records in the ancient Egyptian civilization. Monkeys were prominent animals in ancient Egypt not only because they were considered sacred animals but also because they were treated as pets or extensively trained animals. Moreover, they were highly involved in the daily lives of ancient Egyptians. Even though some animals in ancient Egypt only adhered to a ceremonial role, others were regarded as pets, guards and assets used for barter. The duality and flexibility of the monkey's role are evidently portrayed in the wall depictions. This study focuses on the nonreligious scenes of the monkeys and classifies the mundane life scenes of the monkeys' depictions into main categories. The scenes are collected from various tombs from the Old, Middle and New Kingdoms (more than fifty tombs). The methodology of this research is based on both descriptive data and thorough analysis to accomplish the paper's objectives. The result of this study reveals that the representation of monkeys on the daily life scene can be classified into five categories which are: pets, natural animal behaviors, trained intelligent animals, with attendants and lastly, depictions of monkeys in comic representations. Sometimes a certain representation may be regarded as a mixture of two categories such as a pet and comic or an animal behaviour and a pet.
\end{abstract}

Key words

Monkeys, daily life, Ancient Egypt 


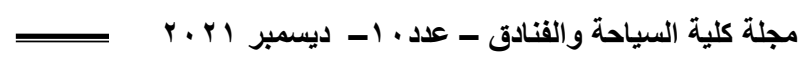

\section{Introduction}

Animal depictions are abundant in visual records in the ancient Egyptian civilization. The role of monkeys through the iconography of Egyptian wall painting is multifaceted. These images indicate a venerable tradition of many types of relationships between humans and many types of monkeys. Monkeys were prominent animals in ancient Egypt not only because they were considered sacred animals but also because they were treated as pets or extensively trained animals. Moreover, they were highly involved in the daily lives of ancient Egyptians. Even though some animals in ancient Egypt only adhered to a ceremonial role, others were regarded as pets, guards and assets used for barter. The duality and flexibility of the monkey's role are evidently portrayed in the wall painting'. 'The images of animals indicate that ancient Egyptians managed to reproduce accurately their physical appearance and defining features' ${ }^{r}$. Although wall scenes supplied us with much information about animals in ancient Egypt, the degree to which those wall scenes reflect the reality is still a matter of arguments ${ }^{r}$. Monkeys in ancient Egypt were not only represented as sacred animals but also as pets or as trained intelligent animals in the daily life scenes. Monkeys

'H. Pio, Baboons in ancient Egyptian Art: The significance of the Baboon motifs (Stellenbosch University, $r \cdot 1 \wedge$ ), $r$ r.

'L. Evans, Animal behaviour in Egyptian Art: representations of natural world in Memphite tomb scenes (Oxford,,$\cdot \cdot \cdot \cdot)$, .

G. Robins, Problems in Interpreting Egyptian art, $D E$ IV $(199 \cdot), \leqslant 0-01$.

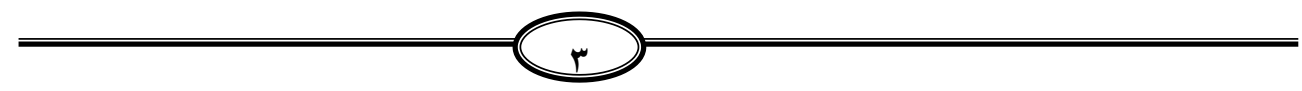


were second only to dogs in popularity as pets in Egypt. They were appreciated for their comic appeal. Monkeys were involved in entertainment and harvesting activities as well ${ }^{\varepsilon}$. There are many studies of monkeys in the ancient Egyptian religion while very few shed lights on monkeys as a natural animal in ancient Egypt.

This study aims to classify the daily life scenes of monkeys into main categories through examining the nonreligious scenes of monkeys. Those scenes were collected from the private tombs in Egypt from the Old to the New Kingdoms such as Giza, Saqqara, Beni Hassan, Meir, Deir el Gabrawy, Hawawish and Thebes in order to explore the different roles of that animal and to follow the development of its roles. This study is applying a descriptive and analytical methodology to achieve its aims. This study has examined more than fifty tombs to set the classified daily life categories of monkeys.

According to the evidence of animal necropolis and wall scenes there were five types of monkeys found in ancient Egypt during its ancient history: the sacred baboon (Papio Hamadryas), the olive baboon (Papio Anubis), the green or vervet monkey (Cercopithecus aethiops), the red monkey (Cercopithecus patas) and the barbary ape (Macaques) but the most common of them were the Hamadryas baboon and the green vervet monkey .

P.F. Houlihan, Harvesters or monkey business?, GM $10 \mathrm{~V}$

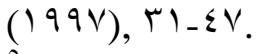

J. Goudsmith and D. Brandon-Jones, Mummies of Olive Baboons and Barbary Macaques in the Baboon Catcomb of 
From the Old Kingdom to the New Kingdom there are many scenes depicting monkeys with attendances as a part of gifts, booty or offerings. Various scenes are depicting these creatures participating in fig harvests or climbing doom palms. Monkeys are also depicted performing dances and playing music. They are also presented at winepresses and even helping with the toilet in the women's chamber, other scenes represented monkeys as pets under the chairs of the owners of the tombs as well as with their keepers. Other scenes are depicting monkeys with a natural animal behavior and as trained animals engaged in various human activities". From the New Kingdom, there are particularly common depictions of monkeys portrayed in various playful human poses on ostraca and papyri. Though particularly on New Kingdom ostraca there may have also been an element of humor ${ }^{\mathrm{V}}$. Vervet monkeys are commonly represented in the Old Kingdom. Early depictions of vervet monkeys show them leashed to a belt around their waist. In the late fourth and fifth dynasties most of them are shown leashed to a collar and at the time of the sixth dynasty some examples of monkeys wearing a collar and a belt appear. At the time of the Middle Kingdom they were not leashed at all but at the time of the New Kingdom they were leashed to belts again ${ }^{\wedge}$.

the sacred animal necropolis at North Saqqara, JEA 10 $(1999), \leqslant 0$.

P.F. Houlihan, GM IOV, r'.

${ }^{2}$ D. Kessler, Monkeys and baboons in ancient Egypt, The Oxford Encyclopaedia of ancient Egypt $\left.\left.r^{(}(\ldots)\right), \leqslant \uparrow \Lambda_{-} \leqslant r\right\}$.

${ }^{\wedge}$ L. Evans, Animal behaviour in Egyptian Art, $9 \leq \mathrm{n}$. 纟^. 
Firstly, monkeys depicted as pets of the owner of the tomb. Secondly, monkeys depicted with a natural animal behaviour. Thirdly, monkeys depicted as trained intelligent animals. Fourthly, monkeys depicted with attendants and lastly, depictions of monkeys in comic representations. Sometimes a certain representation may be regarded as a mixture of two groups such as a pet and comic or an animal behaviour and a pet.

\section{tomb owner}

1. First category: monkeys as pet animal of the

The first category can be divided into two broad representations, either under the chair ${ }^{9}$ of the owner of the tomb' ${ }^{\prime}$ or with its caretaker or keeper. There are many scenes from the Old and New Kingdoms depicting monkeys under a chair but there is no such depiction in the Middle Kingdom. Monkeys were depicted under the chair of the owner of the tomb as well as under the chair of his wife. Dogs and monkeys are always represented under the

'The scenes of the chairs of the tomb owners reveal large numbers of items underneath. Those items can be classified into several groups. The first group represents animals belonging to the owner such as dogs, cats and monkeys. The second group shows objects including: chests, mirrors, vessels, flowers and other items. The third group represents people related to the tomb owners such as his wife, children, servants, in addition to captives. E. El-Kilany and H. Mahran, What Lies Under The Chair: A Study In Ancient Egyptian Privat Tomb Scenes, part 1, JARCE o1 $(r+10), r \leqslant r-T \leqslant$.

"E. El-Kilany and H. Mahran, JARCE $01, r \leqslant 9$. 
chair of the male figures in the Old Kingdom while cats and monkeys are commonly represented under the chair of female figures in the New Kingdom" The notion, however, that monkeys were represented under the chair of the wife of the owner of the tomb due to the sexual abilities of monkeys ${ }^{\prime r}$ seems inadequate, since monkeys were represented under the chair of the male owner of the tomb as well. In the Old Kingdom Most of the representations of monkeys under chairs are depicting vervet monkeys, not baboons. They were represented alone or with other animals mostly with dogs and once with a leopard (cf. the scene of a vervet monkey and a leashed leopard ${ }^{\prime r}$ are led by dwarf from the tomb of Ni-ankh-nswt, Saqqara, $7^{\text {th }}$ Dynasty). During the period of the New Kingdom they were also represented with dogs and rarely with cats and geese. Monkeys were commonly represented eating figs or doom dates. During the Old Kingdom, they are represented with dwarf caretakers.

Dating to the Old Kingdom at Giza, at the mastaba of Nuneter ' , there is a scene with a vervet monkey standing on his four limbs and bound with a rope over its waist and over its neck under the chair of the deceased (fig. '). Also

" E. El-Kilany and H. Mahran, JARCE $01, r \leq 9$.

ir L. Manniche, Sexual life in ancient Egypt (London, 199v), $\leqslant$.

${ }_{15}^{14}$ L. Evans, Animal behaviour in Egyptian Art, 110 n. ${ }^{4}$. H. Junker, Gîza X. Der Friedhof südlich der Cheopspyramide. Westteil (Wien, 1901), $\leqslant \leqslant \leqslant 0$. 
at the mastaba of Idu ${ }^{10}$, there is another scene of a monkey under the chair of the deceased but this time the monkey stands over the head of a dwarf (fig. $r$ ). From Saqqara there are many scenes, for example in the tomb of Ptahhotep ${ }^{17}$, where a scene depicts a pet keeper grasping three ropes of two dogs and a monkey depicted under the chair of the tomb owner. There is a very unique scene in the tomb of Inumin ${ }^{\prime v}$ representing a monkey and a dog under the chair of the owner of the tomb in a very playful posture. The dog is crouching and twisting his head to the back, while the monkey is standing on his two legs over the back of the dog (fig. ${ }^{\text {}}$ ). This scene may be added to the comic group as well.

From Sheikh Saied, in the tomb of Serefeka ${ }^{\wedge \wedge}$ which dates back to the fifth Dynasty there is a representation of a dwarf and a monkey under the chair of the owner of the tomb. The monkey is depicted seated on his legs, eating from a basket full of fruits placed on the ground. In front of him a dwarf stands holding a leash. At Deir el Gabrawi, there is a scene in the tomb of $\mathrm{Aba}^{19}$ depicting a female

10 H. Junker, Gîza VIII. Der Ostabschnitt des Westfriedhofes. Zweiter Teil (Wien ( $19 \leqslant \mathrm{v})$, ro.

${ }^{17}$ J. Vandier, Manuel D Archéologie Egyptienne ะ (Paris, ।97 9 ), fig. 71 .

'v N. Kanawati, The Teti Cemetery at Saqqara viii, The Tomb of Inumin, ACER $r \leqslant(r \ldots r), \leqslant r$, pl. $r \tau$.

is N.de G. Davies, the Rock Tombs of Sheikh Said (London, 19.1), 1r, pl. iv.

19 N.de G. Davies, E.C. Walter and B. George-Albert, The Rock Tombs of Deir el Gebrâwi \' (London, I9.r), pl. r. 
monkey under the chair of the owner of the tomb. That monkey has been provided with a big basket full of fruits. It has been dressed with bracelets, anklets and a collar like a woman and it seems to be happy (fig. 7 ).

In the New Kingdom tomb of Ptahemwia at Saqqara $^{r \cdot}$, there is a scene of a monkey under the chair of the tomb's owner in a joyful pose (fig. $\wedge$ ) similarly to the scene in the tomb of Raia ${ }^{r}$ at Saqqara dating to the Ramesside period which is representing a monkey under the chair playing with some falling fruits such as figs and grapes (fig. \&). A nice example of a monkey standing under the chair of the tomb's owner can be seen also in one relief preserved in the Cairo Museum (temp. Nr. $r o / \tau / r \leqslant / \tau$ ). It belongs to the tomb of Ptahmes recently discovered during the Cairo University excavations at $\operatorname{Saqqara}^{r+}\left(\mathrm{fig} \cdot{ }^{\circ}\right)^{r+}$.

r. M.J. Raven, R. van Walsem, B.G. Aston, L Horáckov and N. Warner, Preliminary report on the Leiden excavations at Saqqara, Season $r \cdots v$ : the tomb of Ptahemwia, JEOL $\varepsilon \cdot(\uparrow \cdot V)$.

A picture showing a monkey under Ptahemwia's chair fig. - (page $r \varepsilon$ ). And The picture of the monkeys eating dates under the chair of Ptahemwia's wife is fig. 9 (page $r v$ ) of the same article (Ibid).

r) G. Martin, The Hidden Tombs of Memphis: New Discoveries from the Time of Tutankhamun and Ramesses the Great (London, 1991), ro, fig. r.

ir G. Martin, Corpus of reliefs of the New Kingdom from the Memphite Necropolis and Lower Egypt I' (London, 19^v), 1ะ. 
From Thebes, we know many scenes from the tombs of the Eighteenth dynasty depicting monkeys under the chair of the owner of the tombs in different poses and accompanied by different animals such as cats and geese in addition to the traditional companion, the dog. There is a scene in the tomb of Mentuherkhepeshef ${ }^{r \varepsilon}$, that depicts a squatting monkey accompanying a dong under the chair of the owner of the tomb. In the tomb of Userhat ${ }^{\text {ro }}$ there are two different depictions of monkeys eating figs under the chair of the wife of the owner of the tomb. In the tomb of Enen ${ }^{r}$ there is a unique representation of a monkey under the throne of king Amenhotep III and queen Tiy. The monkey is represented jumping over a cat and a goose under the , $a$ and b). This 1 ' same chair at a very lively movement (fig. scene can also be added to the comic group.

As for the representation of monkeys with their caretakers or keepers, there are many representations of such scenes at the Old Kingdom. They are usually

For a picture of this relief see J. Berlandini and V. Memphitica, Monuments de la chapelle funéraire du gouverneur Ptahmès, Bulletin de l'Institut Français

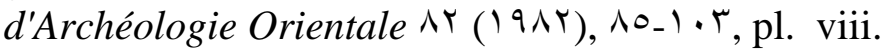

$r \leq$ N.de G. Davies, Five Theban tombs:(being those of Mentuherkhepeshef, User, Daga, Nehemawäy, and Tati (London, $191 \%$ ), pl. ₹.

ro C. Beinlich-Seeber, and A. Shedid, Das Grab des Userhat (TT 07). No. ‥ ( $9 \wedge \vee$ ), Taf.।.

ir N.de G. Davies, The Egyptian Expedition 19r^_/9r9: The Graphic Work of the Expedition. Bulletin of the Metropolitan Museum of Art Yo, no. 11 ( (9r•). fig. I. ?. 
represented with dogs at different poses and attitudes. Many scenes are depicting the caretakers as dwarfs and those dwarf caretakers are not repeated at the later periods. As for the Middle Kingdom there are only two representations of this scene at Beni Hassan, but they are not as clear as those of the Old Kingdom, while there is no such representation at the time of the New Kingdom. Most of the caretakers hold stick ends with a shape of a human hand, probably to control their pet monkeys. For example at the time of the Old Kingdom, at the mastaba of Sehotepu at Giza ${ }^{\text {TV }}$, there is a scene of a man leading a dog with a vervet monkey on its back. In the mastaba of $\mathrm{Ti}^{\mathrm{r}}$ at Saqqara there is a scene of a dwarf leading a bounded vervet monkey with one hand while with the other one he holds a stick end with a shape of a hand. There are many scenes dating back to the sixth dynasty at Saqqara such as the one in the tomb of Ankhmahour ${ }^{\text {qq }}$, depicting a dwarf who carries a vervet monkey over his shoulder while he follows the owner of the tomb (fig. ${ }^{r}$ ). Also in the tomb of Kagemnir ${ }^{r \cdot}$ there is a scene showing a dwarf who leads two dogs and a vervet monkey both of them on a leash (fig.) •). In the tomb of

${ }^{r v}$ H. Junker, Giza XI. Der Friedhof sudlich der Cheopspyramide. Ostteil (Wien, 190r), Abb.r4.

i^ H. Wild, Le Tombeau de Ti. Fascicule III, La chapelle (deuxième partie) ( Le Caire, 19r 1 ), pl. I r .

rq N. Kanawati, and A. Hassan, The Teti cemetery at Saqqara r: The Tomb of Ankhmahor (Warminster, 199v), pl. $\leqslant$ r.

r.W. Wreszinski, Atlas zur Altägyptischen Kulturgeschichte, Bd. III (Leipzig, $19 \leftrightarrow \wedge$ ), taf.^، 9 . 
Mererouka ${ }^{r \prime}$ there is a similar scene with the difference that the male caretaker is not a dwarf (fig. $\vee$ ). At Meir the sixth dynasty tomb of Pepiankh ${ }^{r r}$ contains a scene of three vervet monkeys moving freely with their keepers in front of the seated figure of the tomb owner, while two of them are represented at the head and shoulders of their keepers and the last one is depicted climbing down a small building. At Deir el Gabrawy, there is a scene in the tomb of Zau ${ }^{r r}$, representing two spotted dogs and a monkey walking in front of their master. They can be considered to be his animal pets.

From the time of the Middle Kingdom there are only two scenes in the tombs of Beni Hassan. One of them is to be found in the tomb of Baket III ${ }^{\text {r }}$ which dates back to the eleventh dynasty. The scene represents baboons and vervet monkeys among other animal pets of the owner of the tomb, the last one being a female monkey that carries its baby over its back. All animals are led by the keeper holding the usual stick with hands to control the animals (fig. ' $\wedge$ ). There is no such representation (monkeys with their keepers) during the New Kingdom.

This study has examined about fifty scenes of monkeys under the chairs. The Vervet Monkey is the most

I) P. Duell, The Mastaba of Mereruka, Part I: Chambers A 1-1.(The Chicago, 194^), pl. ₹7.

rr A.M. Blackman, and M. R. Apted. The Rock Tombs of Meir ${ }^{\circ}$ (London, 190r), pl.r'.

$r$ N. de G. Davies, E.C. Walter, and B. George-Albert, The Rock Tombs, pl. IX.

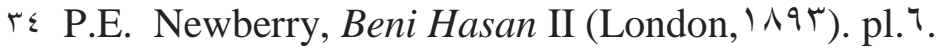


popular type of monkey that is depicted under the chair. They were represented under the chair with dogs, cats, geese and caretakers. It is very common to find a monkey eating fruits or playing with figs or with a basket of fruits in front of him. Monkeys are frequently depicted standing on their two limbs, four limbs or seated. The number of scenes depicting a monkey is second in number to those of dogs during the Old Kingdom and the first in number during the New Kingdom which is a strong indication on the monkey's popularity $^{\text {ro }}$.

\section{behaviour}

r.) Second category: monkeys with natural animal

The second group can be divided into three broad depictions: aggressive behaviour, locomotor behaviour (movement, specially climbing) and ingestive behaviour (eating).

Aggressive behaviour is rarely represented. Only four representations existed at the time of the Old Kingdom, most of them for baboons, which are rarely represented during the Old Kingdom. There is an attacking scene at the market place in the tomb of Tepemankh ${ }^{r \uparrow}$ at Saqqara, which is depicting two leashed baboons under the control of a male keeper. On the left a female walks while clutching an infant to her chest. The other male baboon attacks a young boy (fig. $r \cdot$ ). In another similar scene in the tomb of

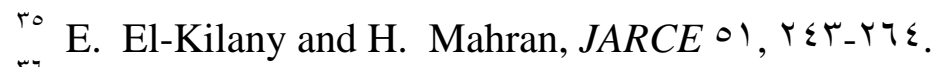

${ }^{\top}$ L. Evans, Animal behaviour in Egyptian Art, $1 \leq 0$, figs. II-rv. 
Niankh-khnum-hetep $^{r v}$, a leashed baboon also attacks a young man, but this time it has succeeded in biting the boy on his leg (fig. Yl). There is also a similar scene at the marketplace scene from the causeway of king Unas ${ }^{r \wedge}$ with a representation of a pair of baboons. There is a scene from Meir $^{r q}$, which dates back to the sixth dynasty. It depicts a vervet monkey jumping over the backs of two dogs and attacks (or plays?) with the face of its caretaker (fig. $r$ ). There is no similar representation at the time of the Middle or New Kingdoms.

Locomotor behaviour (movement of animals) has been defined as it is comprised of different methods by which animal travel through the environment (walk, run, climb, swim, etc.) and the postures and movement associated with these methods and it is also dictated by their physical structure, the type of habitat in which they live and their pattern of activity ${ }^{\varepsilon .}$. The most important scenes representing monkeys involved at the movement behaviour is related with climbing and walking specially at ships scenes. It is very common at the Old Kingdom to depict vervet monkeys climbing and moving freely at the mast of ships especially trading ships. Such scenes can be

${ }^{r v}$ L. Evans, Animal behaviour in Egyptian Art, figs. 9_ $r \varepsilon$.

${ }^{r \wedge} \mathrm{W}$ S. Smith, The Origin of Some Unidentified Old Kingdom Reliefs, $A J A \leq 7$ ( $19 \leqslant 9$ ), fig. ^.

${ }^{\top 9}$ A.M. Blackman, The Rock Tombs of Meir \&, The TombChapel of Pepi 'Onkh the middle son of Sebkhotpe and Pekhernefert (D, no. r) (London, I $9 r \varepsilon)$, pl. IV.

¿. L. Evans, Animal behaviour in Egyptian Art, r. 
found in the tombs ofSnefruanymeret" (fig. $r \tau$ ), Merirouka $^{\varepsilon r}, \mathrm{Mehu}^{\varepsilon r}$ and Hesi ${ }^{\varepsilon \varepsilon}$ from Saqqara. There are also other scenes from Hamamiya ${ }^{\text {¿o }}$ (fig. 19 ), Deshasha ${ }^{\text {} 1}$ and Deir el-Gabrawy ${ }^{\xi v}$. Lastly a scene from Meir ${ }^{\text {} \wedge}$ represents a vervet monkey climbing the ceiling of the chapel of the owner of the tomb. There is also a scene from Elkab $^{\text {sq }}$ dating back to the second intermediate period. It represents monkeys moving freely on a boat. The only scene representing that freely movement behaviour at the New Kingdom is from Deir el-Bahri ${ }^{\circ}$, which is depicting baboons moving freely on ropes of ships. Another scene in

\&) G. Jequier, Essai sur la nomenclature des parties de bateaux. BIFAO 9(1911), pl. 1 .

\&r P. Duell, The Mastaba of Mereruka, Part II: Chambers $A_{\varepsilon r}^{A} 11-1 r$ (Chicago, 19r^), Tf. 19.

\&r H. Altenmüller, Die Wanddarstellungen im Grab des Mehu in Saqqara (Mainz, 199^), Tf. 19.

$\llbracket$ N. Kanawati, and M. Abdel Raziq. The Teti Cemetery at Saqqara $7:$ The tomb of Nikauisesi. ACER ) $\leqslant$ (Warminster, r... $)$, pl.07.

${ }^{2}$ N. El-Khouli, and N. Kanawati, The Old Kingdom Tombs of El-Hammamiya. ACER $r$ (Sydney, 199•) pl. $r \vee \& r \varepsilon$.

${ }_{5}$ N. Kanawati, and A. McFarlane. Deshasha: The Tombs of Inti, Shedu and Others. ACER O (Sydney, 1994), pl.rr.

N. Kanawati, Deir El Gabrawi 1: The Northern Cliff, ACER rT (Sydney, r...0), pl. Tr.

¿^ A.M. Blackman, The Rock Tombs of Meir $\varepsilon, \mathrm{pl}^{r}{ }^{\mathrm{I}}$.

$\leqslant 9$ J. Tylor, and S. Clarke, Wall Drawings and Monuments of El-Kab: The Tomb of Sebeknekht (London, 1^97), pl.r. -. E. Naville, The Temple of Deir el Bahari III (London,

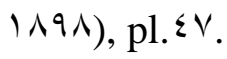


the tomb of Rekhmire represents a monkey climbing the neck of a giraffe ${ }^{\circ}$. There are many scenes representing monkeys climbing doom palm trees and date palm trees, but this theme has been classified under the group of trained monkeys as intelligent animals.

Thirdly, ingestive behaviour (eating): Vervet Monkeys are omnivores. "Fruits, seeds, leaves, flowers, grasses and invertebrates are included in their diets. They are also extremely dexterous and use their hands constantly while feeding. When they eat fruits or leaves from trees, they usually represented seated in order to free their hands for reaching and holding items" " They are commonly represented eating figs and doom nuts from a basket or a bowl. For example from the Old Kingdom, there are scenes from the tombs of Kanefer ${ }^{\circ r}$ at Giza, Ankhmahor ${ }^{\circ \text {, }}$, Niankhkhnumhotep $^{\circ 0}$, Mehu ${ }^{\circ 4}$ and Nikawisesi ${ }^{\circ v}$ (fig. IV) at Saqqara and the tomb of Aba at Deir el-Gabrawy. At the time of the Middle Kingdom there is only the famous scene of the fig tree in the tomb of Khnumhotep at Beni Hassan ${ }^{\circ \lambda}$

-1 N.de G. Davies, The tomb of Rekhmire at Thebes (New York, $19 \leqslant r)$, pl. $r \cdot$.

or L. Evans, Animal behaviour in Egyptian Art, 90 .

or G. Reisner, A History of the Giza Necropolis I (Cambridge, 19ะr), fig. r $r$ r.

$\circ \leqslant$ N. Kanawati, and A. Hassan, The Teti cemetery, pl. $\leqslant$ r.

00 L. Evans, Animal Behaviour in Egyptian Art, fig. $V_{-} \mathrm{r} q$.

or H. Altenmüller, Die Wanddarstellungen, Tf. 19.

${ }^{\circ} \mathrm{N}$. Kanawati, and M. Abdel Raziq. The Teti Cemetery, pl. $\_$.

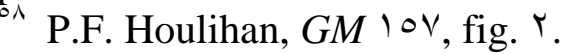


which depicts three baboons on a fig tree eating figs and playing with each other (fig. ${ }^{\wedge}$ ). At the time of the New Kingdom there are many scenes representing monkeys under the chair of the owner while eating and many scenes are representing monkeys sitting in front of baskets full of figs or doom-nuts and happily eating their favourit fruits. This representation was found in the tomb of Userhat. Linda Evans has mentioned in her valuable recent study about animal behaviour in Egyptian art that the Egyptian images represent accurately the behaviour of monkeys when eating small fruits such as figs and doom nuts ${ }^{\circ 9}$.

\section{animals \\ ґ.) Third category: monkeys as trained intelligent}

The third group can be divided into two types: possible works and questionable works. The first type includes monkeys carrying a heavy load, helping with the squeezing of grapes, dancing and doom-nut harvesting. The second type includes monkeys as musicians, hair dressers, policing at the marketplace and directing boat building while wielding a foreman's baton.

For the possible work there is only one unfinished scene from the tomb of Ni-ankh-pepi at Zawyat elMayiteen from the Old Kingdom which represents a strong monkey carrying a heavy load using a shoulder yoke ". It is not clear whether he is helping in building something or just transfers these loads from one place to another. There is

${ }^{9}$ L. Evans, Animal behaviour in Egyptian Art, 90.

A. Varille, La tombe de Ni-Ankh-Pepi à Zaouyet ElMayetin (Le Caire, 19r^), pl.'।. 
a similar scene from the New Kingdom of a monkey carrying two jars of water using a shoulder yoke too, but this time to water the garden ${ }^{T \prime}$

The second possible work which has no equivalent is the representation of a baboon helping with the twisting of the must sack during the squeezing of grapes to make wine in the tomb of Nefer ${ }^{\text {Tr }}$ at Saqqara from the Old Kingdom (fig. ${ }^{r}$ ). Although the previous two possible works are not repeated, it is logically possible to be true.

The third possible and logic work for monkeys is as dancer for the entertainment of people, which regularly appear at our modern circus and at the streets of some areas at Cairo today. For example, there is a representation in the tomb of Serefeka at Sheikh Saied from the fifth dynasty representing a monkey dancing behind a group of female dancers and followed by two clappers ${ }^{\top}$ (fig. 17 ). During the Middle Kingdom there is a representation in a tomb at Beni Hassan depicting a priest and a monkey rehearsing for a certain dance and this particular scene was used as a determinative for the iwn-mwt=f priest which may indicate that the priest iwn-mwt=f was responsible for the training of monkeys for a religious dance ${ }^{\text {. }}$. There are also many representations from the New Kingdom on ostraca from

" J. Vandier d'Abbadie, Les singes familiers dans l'ancienne Égypte. $R d F$ 1^(1974), 19ץ-19ะ, fig. ${ }^{\circ}$.

A. Moussa and H. Altenmüller, The tomb of Nefer and Ka-hay. $A V \circ$ (Mainz, 19Y।).

${ }^{\top}$ N.de G. Davies, the Rock Tombs, pl. IV.

i F.L. Griffith, Beni Hasan III. No. ○ (London, 1^97), pl.AY_Ar. 
Deir el-Madina representing a vervet monkey rehearsal for dancing with a boy and another monkey dancing during playing on a flute ${ }^{10}$ (fig. ${ }^{r} \cdot$ ).

The fourth possible work is as harvesters of figs, doom-nuts and dates. There is a representation in the tomb of Nefer maet and Atet at Maydum ${ }^{14}$ from the Old Kingdom which represents a vervet monkey climbing a fig or sycamore tree but it is not clear whether he is collecting fruits or eating them. There is also the most famous scene of baboons collecting figs in the tomb of Khnum Hotep ${ }^{\text {TV }}$ (fig. ${ }^{\wedge} \wedge$ ) at Beni Hassan from the Middle Kingdom. This scene represents three baboons on a fig tree (picking or eating?) figs. They may be helping two men harvesting figs from a tree heavy with ripe fruits. Instead of assisting them the hungry monkeys were depicted busy eating these figs, which they are fond of. Most of the scenes which represent that work date back to the New Kingdom. A scene in the tomb of Ptahemwia ${ }^{\text {} \Lambda}$ at Saqqara represents a monkey or two, climbing date palms to gather the dates as well (fig. $Y$ V). Another ostracon at Deir el Madina ${ }^{79}$ represents

10 J. Vandier d'Abbadie, Catalogue des Ostraca figurés de Deir el-Médineh, FIFAO ${ }^{r}$ (Le Caire, $19 \leqslant \uparrow$ ), no. ${ }^{r} \cdot \varepsilon r$.

ז Fl. Petrie, Meidum (London, $1 \wedge 9 \curlyvee$ ), pl.'^.

iv C. Singer, and et al., A History of Technology I (Oxford, $190 \varepsilon), 0 \leqslant 0$, fig. ${ }^{4} \mathrm{r}$.

is M..J. Raven, and M. H. Harold, The Tombs of Ptahemwia and Sethnakht at Saqqara (Sidestone Press, r.r.), $\wedge \cdot-\wedge$ l, fig. [ ' '] IA.

${ }^{19} \mathrm{~J}$. Vandier d'Abbadie, Catalogue des Ostraca figurés de Deir el-Médineh, fasc.I, no. ${ }^{-. .}$. 
the same scene but at a doom-nut palm and the monkeys are tied with ropes to help them doing their works (fig. $r \varepsilon$ ). There is also another scene from a stela ${ }^{\mathrm{r}}$ (Egyptian Mus. JE. $\{79 \wedge r$ ) dating to the New Kingdom, which represents a monkey picking doom-nuts and throwing them into a bowl held by a lady standing behind the monkey.

The first questionable work is making music. It is represented during the Old Kingdom in the tomb of Serefeka at Sheikh Saied ${ }^{\text {v }}$ which represents a monkey sitting behind a female harpist and a female singer while eating from a basket full of fruits in front of it (fig. 17). Another tomb from Saqqara which dates back to the fifth Dynasty contains a representation of a monkey playing the role of a singer with its traditional hand gestures in front of a male harpist ${ }^{v r}$. These two scenes may indicate that monkeys participated with the entertainment team of the owners of the tombs, which might be possible. But monkeys playing the harp or flut is very hard to believe. They are depicted on ostraca from Deir el-Madina dating to the New Kingdom and representing a vervet monkey playing on a double flute while dancing (fig. $r \cdot$ ) and

v. J. Vandier d'Abbadie, Catalogue des Ostraca figurés de Deir el-Médineh, 17, fasc.III, fig. '।.

v) N.de G. Davies, the Rock Tombs, pl. iv.

H.G. Fischer, A Foreman of Stoneworkers and His Family, The Metropolitan Museum of Art Bulletin ' V, no. 7 (1909), 1 $\leqslant 0.10$ r, fig.^. 
another one depicting a monkey sitting and playing a harp ${ }^{\mathrm{v}}$ (fig. ${ }^{9}$ ). These representations might be for fun or for sarcasm and they might better be added to the comic representations.

The second questionable work is that of a hair dresser and some activities related to this work. In the tomb of Sebeknakht at El-Kab ${ }^{\gamma \varepsilon}$ dating back to the seventeenth dynasty, there is an unrepeated depiction of a monkey helping a maid at the hair dressing of their mistress but both, the maid and the monkey are represented in a very small scale. In the tomb of Bebi also at El-Kab ${ }^{\mathrm{V}_{0}}$, there is a unique depiction of a spotted monkey under the chair of the owner of the tomb and his wife, tied with a rope to the leg of the chair and holding a mdt vessel which contains a perfume ointment (fig. I $\leqslant$ ). It is difficult to believe that monkeys are actually involved in hair dressing of ladies in ancient Egypt. However, there are many vessels of perfume and kohl, hair pins and jewellery boxes decorated with the figure of a monkey ${ }^{\mathrm{V}}$. In addition to the fact of representing monkeys under the chair of the mistress of the tomb especially during the New Kingdom period. All these facts

vr J. Vandier d'Abbadie, Catalogue Des Ostraca Figurés De Deir El Medineh:Fasc. r. (Le Caire: impr. de l'Inst. fr. d'archéol. orient, $19 r \mathrm{~V})$, no. ${ }^{\prime} \cdot{ }^{\prime} r$ pl.IX.

${ }^{\mathrm{V}} \mathrm{J}$ J. Tylor, and S. Clarke, Wall Drawings, pl. '^. vo J. Vandier, Manuel D Archéologie, IVฯ, fig. 70.

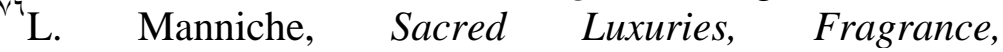
Aromatherapy, and Cosmetics in Ancient Egypt. (London, 1999), 7.-1\%. 
may support the opinion of Manniche ${ }^{v v}$ of the sexual power of monkeys.

The third questionable work is policing at the marketplace. At the time of the Old Kingdom there are two scenes in the tombs of Tepemanhk and Niankhkhnum at Saqqara (figs. $19_{-} r_{\bullet}$ ), depicting unique representations of baboons attacking and biting boys or a thieve at the market place which may indicate that monkeys were policing at the market. Based on the accompanied inscription it has been suggested that these boys were caught by the baboon while trying to steal. According to Evans ${ }^{\mathrm{r}}$, the Egyptian clearly kept the baboons, even they are known to be irritable and aggressive, they are also intelligent and so it may have been possible to train a baboon to chase and bite on command. But she believes that the animals in these scenes have acted spontaneously in response to the sudden movements of the thieves, which have triggered their natural tendency to chase.

The fourth questionable work is directing boat building while wielding a foreman's baton which is represented in a unique scene in the tomb of Nfr-ka-hai from Saqqara dating back to the Old Kingdom ${ }^{19}$ (fig. ${ }^{\circ}$ ). This work is impossible to be true so it is either a sarcastic representation or a sudden movement or behaviour from the baboon and the artist liked to present it.

\footnotetext{
${ }^{v}$ L. Manniche, Sexual life, $\leqslant \varsigma$.

' L. Evans, Animal behaviour in Egyptian Art, $1 \leq 7$.

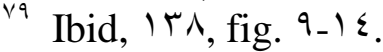

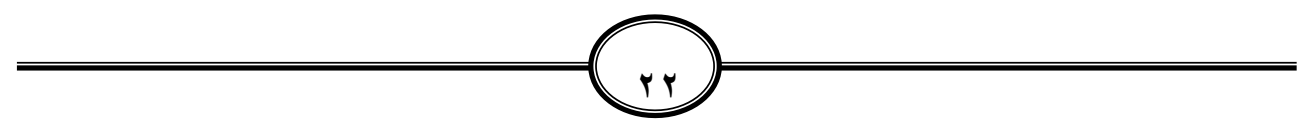




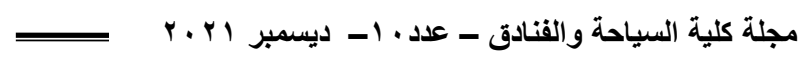

\section{£.) Fourth category: monkeys in tribute scenes and with attendants}

Starting from the Old Kingdom to the New Kingdom there are many scenes depicting monkeys with attendances as a part of gifts, booty or offerings.

There are a lot of scenes from the Old Kingdom such as a scene, which dates back to the fourth dynasty from the tomb of Mersankh III ${ }^{\wedge}$, representing a vervet monkey with a female servant who carries the funerary furniture of the queen. This scene is considered to be the only scene representing monkeys with female attendants (fig. Ir). From the time of the fifth dynasty at the mastaba of Kanfer $^{\wedge}$ ' there is a depiction of a line of male attendants among them a dwarf holding a vervet monkey over his head. From the time of the sixth dynasty, in the tomb of Ankhmahour ${ }^{\wedge r}$ there is a scene representing male attendants or offering bearers and one of them is accompanied by a monkey on a leash and above the monkey is written his name Mer-redis which means the love she gives. In the tomb of Hesi ${ }^{\wedge r}$ there is a scene of offering bearers on the marches landscape. One of these bearers is a dwarf leading

^. W.K. Simpson, Mastabas of the Western Cemetery I (Boston, 19^•), fig.^.

^) G. Reisner, A History of the Giza, fig. rז.

${ }^{\wedge}$ N. Kanawati, and A. Hassan, The Teti cemetery, ${ }^{\wedge}$, pl. ¿).

N. Kanawati, A. Hassan, M. Abd El-Raziq, The Teti cemetery at Saqqara VI (Warminster, 1999), pl.०ะ. 
a vervet monkey and a dog to give them as offering pet animals to the owner of the tomb.

There is no similar scene at the time of the Middle Kingdom but at the time of the New Kingdom there are many scenes such as that of the temple of Dair el-Bahri of Hatshepsut $^{\wedge}$ which represents a male attendant leading a baboon. Also, in the tomb of Rekhmire ${ }^{{ }^{\circ}}$ there are many representations of monkeys at different poses. There are male attendants with vervet monkeys and baboons tied with ropes. In the tomb of Amunedjeh ${ }^{\wedge \uparrow}$, there is a very interesting tribute scene which represent monkeys as a part of the gifts from the chief of the land of Punt to the owner of the tomb. There are three depictions of monkeys; the first one, which is unique, represents a green monkey with a red face sitting on a high stool carried by a man. Like the previous tomb there is another representation of a monkey over the back of a giraffe (fig. ro) and lastly there is a baboon and a vervet monkey led by two attendants.

\section{๑) Fifth category: monkeys in comic representations}

The fifth group of representations is related to the natural movements and sounds of monkeys that are used to amuse and entertain people, especially children. There are few representations of this kind at the time of the Old and Middle Kingdoms, which goes with the formal type of art,

${ }^{\wedge}$ E. Naville, The Temple of Deir el Bahari, pl. $\vee \uparrow$. ${ }^{10}$ N.d.G. Davies, The tomb of Rekhmire, $19 \leqslant$, pl.r. $\wedge$ ч.M. Davies, Nubians in the Tomb of Amunedjeh. JEA $\uparrow \wedge$ ( $9 \leqslant Y), \mathrm{pl}$. V. 
which was depicted at that time. At the time of the New Kingdom especially on the ostraca from Deir el-Madina, with the great sense of humour the workmen had and with the feeling of no strains or canon over them, they really had brought to us very comic and funny representations of many topics especially monkeys ${ }^{\wedge V}$.

At the time of the Old Kingdom, in the tomb of Nefer maet and Atet at Medum ${ }^{\wedge \wedge}$ (early fourth dynasty) there is a representation of two vervet monkeys with leashes playing with their two keepers and one of the monkeys puts his hand over the shoulder of his keeper in a very familiar and funny touch. Another scene in the same tomb represents a monkey holding a boy from his hand while the boy is touching another monkey walking in front of him and the latter monkey is touching a tail of an ibis bird walking in front of him at the same line in a very funny gesture (fig. 1.). In the tomb of Kai-khent dating back to the fifth dynasty at Hamammeya ${ }^{\wedge 9}$, there is a representation of two playful monkeys and a dog under the seated figures of the owner of the tomb and his wife. These pleasured vervet monkeys are represented in a very unique crossing pose never represented before or after (fig. ${ }^{\top}$ ).

Av D. Azmi, Humor scenes as a reflection of Ancient Egyptian Society, A Thesis submitted to Minia University for the Degree of Master in Tourist Guidance, Faculty of Tourism and Hotels $(r \cdot 10)$.

$\wedge$ Fl. Petrie, Meidum, pls. $\mid \vee, \wedge, \uparrow \leqslant$.

^q N. El-Khouli, and N. Kanawati, The Old Kingdom Tombs, pls. $r v, \leq \varepsilon, T$ T. 
At the time of the New Kingdom in some tombs at Saqqara, which date back to the eighteenth dynasty there are representations of monkeys under the chair of the owner at a joyful pose playing and eating at the same time. These scenes are found in the tomb chapels of Paser and Ra'ia and in the tomb of Khay ${ }^{9}$. At Thebes there are many scenes representing monkeys under the chair of the owner doing many funny and comic movements such as that scene in the tomb of Enen, there is a unique representation of a monkey under the throne of king Amenhotep III and queen Tiy ${ }^{91}$. It is represented jumping over a cat and a goose under the same chair at a very lively movement. Also in the tomb of Rekhmire $^{q r}$ there are many representations of monkeys at different poses. There is a representation of a monkey climbing a neck of a giraffe. The second one is a depiction of a female monkey sitting on a chair without a back and eating figs from a near basket. On a stela ${ }^{9 r}$ dating back to the nineteenth dynasty there is a depiction of a standing monkey under the chair of the owner of the tomb facing a cat in a very funny pose. There is also another funny and comic depiction in the tomb from the Ramesside period of a monkey catching a goose or playing with a goose under the chair of the owner of the tomb ${ }^{\text {qई }}$. On ostraca from Deir elMadina there are many representations of a monkeys in

१. G. Martin, The Hidden Tombs, ro, fig. ^r.

9) N.de G. Davies, The Egyptian Expedition 19MA-19ra, figs. I.7.

qr N.d.G. Davies, The tomb of Rekhmire, $19 \leqslant r$, pls. $r \cdot$. $1 \wedge$. q $\mathrm{J}$. Vandier d'Abbadie, $R d F \backslash \wedge, 1 \wedge \varepsilon$, fig. \&

qะ W. Wreszinski, Atlas zur altägyptischen Kulturgeschichte, Bd. I (Leipzig, $19 r$ r), pl. I r $\mathrm{b}$. 
sarcasm poses like the monkey with a double pipe flute, playing with a girl by a rope, dancing, singing and eating doom nuts ${ }^{90}$. Most of these scenes are representing green vervet monkeys and baboons as well.

Whether animals are represented alone or in groupings, most depictions show a sense of humor. As Houlihan mentioned "In pharaonic Egypt, the images of beloved pets developed into a convenient vehicle for expressing a touch of comic relief within the represented scene from the Old Kingdom onwards."

\section{Conclusion}

After examining the scenes depicting monkeys of more than fifty tombs from all over ancient Egyptian cemeteries from the Old to the New Kingdom few remarks can be concluded:

Theire are five categories of the depiction of monkeys in relation to daily life scenes and they are Firstly, monkeys depicted as pets of the owner of the tomb. Secondly, monkeys depicted with a natural animal behaviour. Thirdly, monkeys depicted as trained intelligent animals. Fourthly, monkeys depicted with attendants and lastly, depictions of monkeys in comic representations. Sometimes a certain representation may be regarded as a mixture of two groups such as a pet and comic or an animal behaviour and a pet.

During the Old Kingdom it was common to represent monkeys under the chair of the owner of the tomb or at the mast of shipping boats or with its caretaker especially

9o J. Vandier d'Abbadie, Catalogue Des Ostraca, nos.

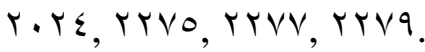


dwarfs. Representing monkeys with attendants is less common than other representations. Representing monkeys involved in different human activities is almost repeated once with all possible and questionable works. The comic touch of monkeys almost accompanied every scene represented at that time.During the Middle Kingdom there were very few scenes (almost three scenes from the tombs of Beni Hassan) representing monkeys among them the famous scene of the fig tree at Beni Hassan.During the New Kingdom representations of monkeys under the chair of the wife of the tomb owner are very common, especially at Saqqara and at Thebes. As well as representing them engaged in the harvest of dates and doom-nuts (climbing the palm tree). There are also many scenes representing monkeys at booty scenes. The most funny and comic representation of monkeys all over the time of Egyptian history came out from the ostraca of Deir el-Madina. Monkeys are rarely represented in the shipping boat scenes during that time.

Vervet monkeys were commonly represented during the Old Kingdom. Both Hamadryas and Anubis baboon are represented in Old Kingdom scenes, but they were not as common as vervet monkeys at that time. Baboons were frequently represented at tombs of the Middle and New Kingdoms. It is also represented frequently on ostraca from Deir el-Madina dating back to the New Kingdom.

Monkeys were represented under the chair of the male owners of the tombs even more times than under those of the wives especially during the Old Kingdom. It should be mentioned, however, that if there is an animal under the chair of the wife it would be a monkey 
Concerning the relation between monkeys and dwarfs, who were commonly represented with each other especially during the Old Kingdom there is no definite answer, but two suggestions are proposed here: firstly they have the same origin and are imported from the same places: Nubia, Sudan and the Land of Punt. Secondly, both of them are part of the endogen of the nobles and wealthy people who is as well responsible for their entertainment. Those dwarf caretakers are not repeated at the later periods because in general dwarfs were rarely represented during the New Kingdom.

Scenes of animal under the chair first attested during the reign of Khafra (Dog in the Fourth Dynasty Giza tomb) and ended during the reign of Pasmatik I (Gazelle in the Twenty sixth Dynasty Theban tomb). Animals are depicted under the chair for their advantages, popularity, sense of humor and their religious importance.

The representations of monkeys with dogs under the care of one person give us an indication that the caretaker who is responsible for monkeys is also responsible for the other pets of the owner of the tombs.

There is an issue of argument about monkeys acting as harvesters: is it just an animal behaviour or is it to be seen as a result of training? However, scholars such as Christiane Ziegler $^{9 \uparrow}$, Patrick Hulihan ${ }^{9 \vee}$ and Dieter Kessler ${ }^{9 /}$

${ }^{9}$ B. Letellier, and C. Ziegler, Le Louvre présente au Muséum de Lyon les animaux dans l'Égypte ancienne: exposition du $T$ novembre $V \gamma$ au $\mathrm{rl}^{\prime}$ janvier $V \wedge$ (Lyon, lavv), ᄉr. 
believe that there were no trained monkeys in ancient Egypt, while other scholars such as Tackholm ${ }^{99}$, Deputte and Anderson '. baboons were used to collect palm nuts as it is depicted on a painting of an ancient Egyptian artifact with striking similarities with the modern use of pig-tailed macaques as coconut harvesters are described. The researcher tends to recommend the second opinion for three reasons: firstly, it's easy to train a naturally climbing animal such as a monkey to do such work. Secondly it is not a strong evidence that was adopted by the first team that most of the represented scenes of monkeys doing that work depicting them eating not collecting the fruits because simply they can do both as a kind of reward for them for helping in the harvesting of these fruits. Thirdly, it is not logic to allow those creatures to reduce the total number of harvested fruit just (economic issue) to permit these animals to have fun.

Finally after displaying all these scenes about monkeys, the study found out that the only existing role of monkeys till our modern days in Egypt is its role in entertainment at the circus and dancing at the street with its owner to draw a smile at the faces of people.

qv P.F. Houlihan, $G M$ lov, rr.

१^ D. Kessler, Monkeys and baboons, ¿rq.

$99 \mathrm{~V}$. Tackholm, and L. Boulos, Additions and Corrections to the Second Edition of Student's Flora of Egypt (Cairo, 19VV), r79.

1.. B.L. Deputte, and J. R. Anderson, Baboon palm nut harvesters in ancient Egypt: new (ancient) evidence, new questions. Folia primatologica $\wedge \cdot$, no. $r(r \cdot . q), v_{\cdot-} r^{r}$. 


\section{Bibliography}

Altenmüller, H., Die Wanddarstellungen im Grab des Mehu in Saqqara (Mainz, 1991).

Beinlich-Seeber, C., Shedid, A. Das Grab des Userhat (TT 0 7). No. ०•. (P. von Zabern, 19^v).

Azmi, D., Humor Scenes as a Reflection of Ancient Egyptian Society, A Thesis submitted to Minia University for the Degree of Master in Tourist Guidance, Faculty of Tourism and Hotels $(Y \cdot 10)$.

Berlandini, J., V. Memphitica, Monuments de la Chapelle Funéraire du Gouverneur Ptahmès, Bulletin de

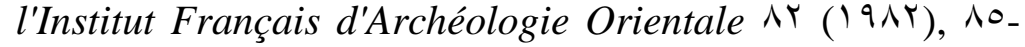
$1 \cdot r$.

Blackman, A.M., The Rock Tombs of Meir \&, The Tomb-Chapel of Pepi 'Onkh the Middle Son of Sebkhotpe and Pekhernefert (D, no. r) (London, $19 r \varepsilon)$.

Blackman, A.M., and M. R. Apted. The Rock Tombs of Meir o, The Tomb-Chapels A, No. ' (That of Ni-'AnkhPepi the Black) A, No. r (That of Pepi 'Onkh with the'good name'of Heny the Black), A, No. ₹ (That of Hepi the Black), D, No. ' (That of Pepi), E, Nos. I- $z$ (Those of Meniu, Nenki, Pepi 'Onkh and Tjetu) (London, 190r).

Davies, N. de G., E.C. Walter and B. George-Albert, The Rock Tombs of Deir el Gebrâwi $\backslash$ (London, 19.r).

Davies, N.de G., the Rock Tombs of Sheikh Said (London, 19.1).

Davies, N.de G., Five Theban tombs:(being those of Mentuherkhepeshef, User, Daga, Nehemawäy, and Tati (London, $191 \%$ ). 
Classification of Monkey's Roles

— Relating to the Daily Life Scenes in

Ancient Egypt

Davies, N.de G., The Egyptian Expedition 19ץ^_ 19r9: The Graphic Work of the Expedition, Bulletin of the Metropolitan Museum of Art ro, no. 11 ( 19 r.), ro_sq.

Davies, N.de G., The tomb of Rekhmire at Thebes (New York, $19 \leq r)$.

Davies, N.de G., The tomb of Rekh-mi-Rē at Thebes 11 (Ayer Company Pub, $19 \vee \mathrm{V}$ ).

Davies, N.M., Nubians in the Tomb of Amunedjeh, JEA $r \wedge(19 \leqslant r)$ : $0 \cdot-0 r$.

Deputte, B.L., and J.R. Anderson, Baboon palm nut harvesters in ancient Egypt: new (ancient) evidence, new questions. Folia primatologica $\wedge \cdot$, no. $r(r . .9), \vee \cdot-\vee r$.

Duell, P., The Mastaba of Mereruka, Part I: Chambers A 1_1. (Chicago, 19r^).

------, The Mastaba of Mereruka, Part II: Chambers A '1_ Ir(Chicago, 19r^).

El-Khouli, N, and Kanawati, N. The Old Kingdom Tombs of El-Hammamiya. ACER r, (Sydney, $199 \mathrm{r})$.

El-Kilany, E., and H. Mahran, What Lies Under The Chair: A Study In Ancient Egyptian Private Tomb Scenes,

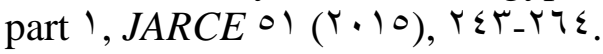

Evans, L., Animal Behaviour in Egyptian Art: Representations of Natural World in Memphite Tomb Scenes (Oxford, Y. '•).

Fischer, H.G., A Foreman of Stoneworkers and His Family, The Metropolitan Museum of Art Bulletin IV, no. 7 (1909), 1 $\leqslant 0_{-} 101$.

Goudsmith, J, and D. Brandon-Jones, Mummies of Olive Baboons and Barbary Macaques in the Baboon Catcomb of the sacred animal necropolis at North Saqqara, JEA ^० (1999), so_ or. 
Griffith, F.L., Beni Hasan: Part III. No. ○ (London, $1 \wedge 97$ ).

Houlihan, P.F., Harvesters or Monkey Business?, GM lov ( (99V), ए।-乏V.

Jequier, G. Essai sur la nomenclature des parties de bateaux. BIFAO 9 ( $(911)$, rv_Ar.

Junker, H., Gîza VIII. Der Ostabschnitt des Westfriedhofes. Zweiter Teil (Wien, 19 $\leqslant$ V).

-------, Gîza X. Der Friedhof südlich der Cheopspyramide. Westteil (Wien, 1901).

-------, Giza XI. Der Friedhof sudlich der Cheopspyramide. Ostteil (Wien, 190r).

Kanawati, N, and A McFarlane, Deshasha: The Tombs of Inti, Shedu and Others. ACER ०, (Sydney, 1994).

Kanawati, N, A., et al., The Teti Cemetery at Saqqara I (Sydney, 1997).

Kanawati, N, A. Hassan, The Teti cemetery at Saqqara r: The Tomb of Ankhmahor (Warminster, 19१V).

Kanawati, N., A. Hassan, M. Abd El-Raziq, The Teti cemetery at Saqqara VI (Warminster, 1999).

Kanawati, N, and M. Abdel Raziq, The Teti Cemetery at Saqqara 7: The tomb of Nikauisesi. ACER Is (Warminster, Y...).

Kanawati, N., Deir El Gabrawi ': The Northern Cliff, ACER Yr (Sydney, r...0).

Kanawati, N., The Teti Cemetery at Saqqara viii, The Tomb of Inumin, ACER $r \leq$ (Warminster, $r \cdots$ T).

Kessler, D., Monkeys and Baboons in ancient Egypt,

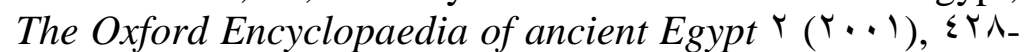
r.

Letellier, B, and Ziegler, C., Le Louvre présente au Muséum de Lyon les animaux dans l'Égypte ancienne: 
Classification of Monkey's Roles

— Relating to the Daily Life Scenes in

Ancient Egypt

exposition $d u \quad 7$ novembre $V \vee$ au $\mathrm{rl}$ janvier $V \wedge$ (Lyon, $19 \vee v)$.

Manniche, L., Sexual life in Ancient Egypt (London, 199V).

-----, Sacred Luxuries, Fragrance, Aromatherapy, and Cosmetics in Ancient Egypt. (London, 1999).

Martin, G., Corpus of reliefs of the New Kingdom from the Memphite Necropolis and Lower Egypt 1 (London, 19^v).

-----, The Hidden Tombs of Memphis: New Discoveries from the Time of Tutankhamun and Ramesses the Great (London, 1991).

Moussa , A, and H. Altenmüller, The Tomb of Nefer and Ka-hay. AV॰ (Mainz, I9V।).

Naville, E., The Temple of Deir el Bahari III (London, $1 \wedge 9 \wedge$ ).

Newberry, P.E., Beni Hasan II (London, $1 \wedge 9$ r).

Pareja, M., Monkey and Ape Iconography in Minor Art (Pennsylvania, r.10).

Petrie, Fl., Meidum (London, ।^९ץ).

Pio, H., Baboons in ancient Egyptian Art: The significance of the Baboon motifs (Stellenbosch University, r. 1 1).

Raven, M. J., and M.H. Harold, The Tombs of Ptahemwia and Sethnakht at Saqqara (Sidestone Press, r. r.).

Raven, M.J., R. van Walsem, B.G. Aston, L Horáckov, and N. Warner, Preliminary report on the Leiden excavations at Saqqara, Season $r \cdot v$ : the tomb of

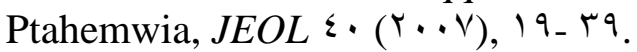

Reisner, G., A History of the Giza Necropolis I (Cambridge, $19 \leq r$ ). 
Robins, G., Problems in Interpreting Egyptian art, $D E$ IV (199.), క0-01.

Simpson, W.K., Mastabas of the Western Cemetery I (Boston, 191.).

Singer, C., et al., A History of Technology I (Oxford, $190 \leqslant)$.

Smith, W S., The Origin of Some Unidentified Old Kingdom reliefs, $A J A \leq 7$ ( $19 \leqslant 9), 010.011$.

Tackholm, V., and L. Boulos, Additions and Corrections to the Second Edition of Student's Flora of Egypt (Cairo, 19vV).

Tylor, J.J., and S. Clarke, Wall Drawings and Monuments of El-Kab: The Tomb of Sebeknekht (London, 11997).

Vandier d'Abbadie, J., Catalogue Des Ostraca Figurés De Deir El Medineh:Fasc. r(Le Caire, 19rv).

Vandier d'Abbadie, J., Catalogue des Ostraca figurés de Deir el-Médineh. FIFAO r, no. r. $\{r$ (Le Caire, 19 1 ૫).

Vandier, d'Abbadie, J., Les Singes Familiers III: le

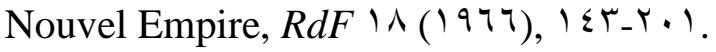

Vandier, J., D. Manuel, Archéologie Egyptienne $\leq$ (Paris, 197 ),

Varille, A., La Tombe de Ni-Ankh-Pepi à Zaouyet ElMayetin (Le Caire, 19r^).

Wild, H., Le Tombeau de Ti. Fascicule III, La chapelle (deuxième partie) ( Le Caire, 1974).

Wreszinski, W., Atlas zur altägyptischen Kulturgeschichte, Bd. I (Leipzig, 19r 19 ).

----, Atlas zur Altägyptischen Kulturgeschichte, Bd. III, ' (Leipzig, 19r^).

\section{List of Figures}


Classification of Monkey's Roles

- Relating to the Daily Life Scenes in Ancient Egypt

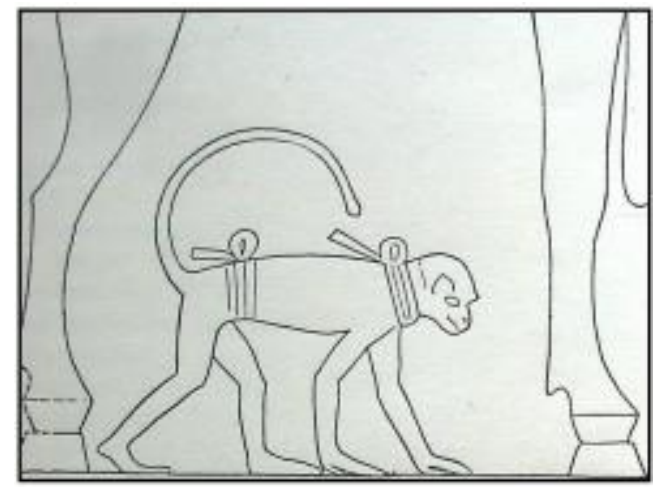

Fig. '

A monkey under the chair of Nunetur the owner of the tomb, O.K

after H. Junker, GIZAX, Abb $\leqslant 0$.

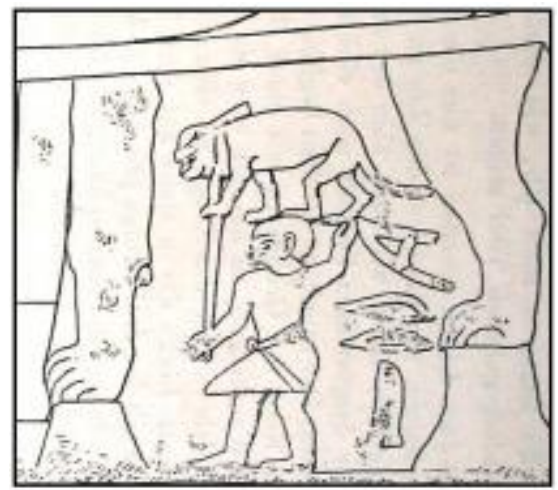

Fig. r

A monkey over the head of his dwarf caretaker under the chair of Idu the owner of the tomb, O.K after H. Junker, GIZA VIII, Abb. ro. 


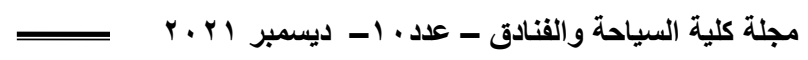

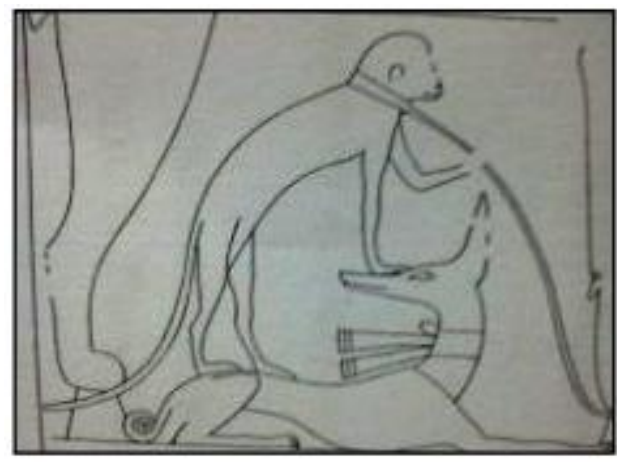

Fig. r

A monkey is jumping over a crouching dog under the chair of the Nunetur the owner of the tomb, O.K after N. Kanawati, The Teti Cemetery at Saqqara, pl. $r$.

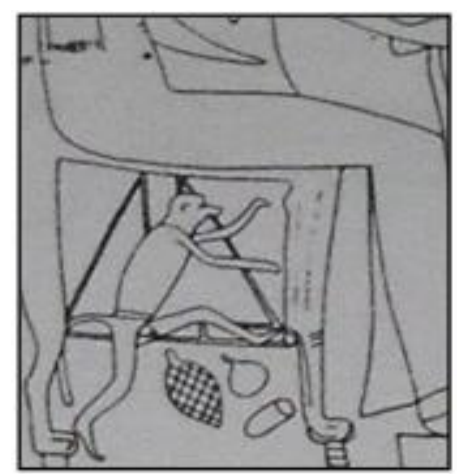

Fig.

A monkey under the chair of Raia (the owner of the tomb), playing with some falling fruits such as figs and grapes, Saqqara, N.K

after G. Martin, The Hidden Tombs of Memphis, fig. 사 
Classification of Monkey's Roles

— Relating to the Daily Life Scenes in Ancient Egypt

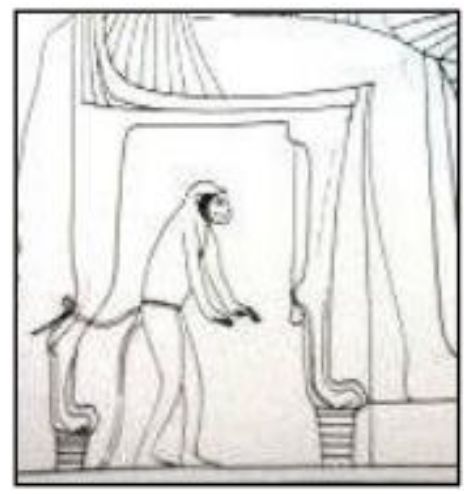

Fig. ${ }^{\circ}$

A monkey is standing under the chair of Ptahmes the tomb's owner, Saqqara, N.K after G. Martin, Corpus of Reliefs, pl. ${ }^{\circ}$.

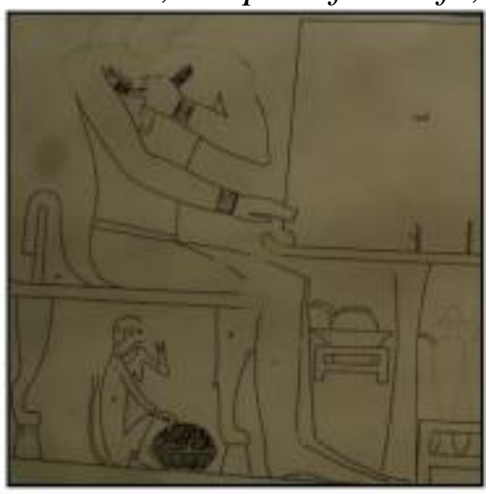

Fig. 7

A female monkey under the chair of the owner of the tomb, that monkey has a big basket full of fruits and dressed with bracelets, anklets and collar like a woman, O.K

after N.de G., Davies, Deir El Gebrawy I, pl.7r. 


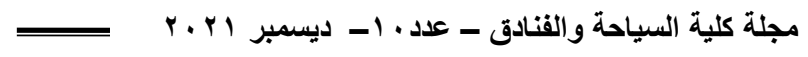

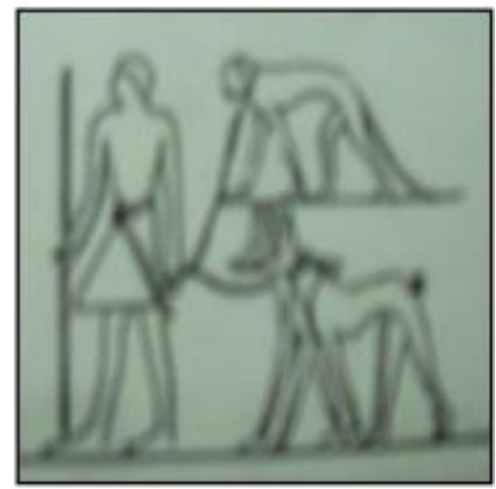

Fig. $\vee$

A caretaker is holding a rope attached to the monkey and two dogs and by the other hand he is holding a stick after

P. Duell. The Mastaba of Mereruka,pl. ₹ ?.

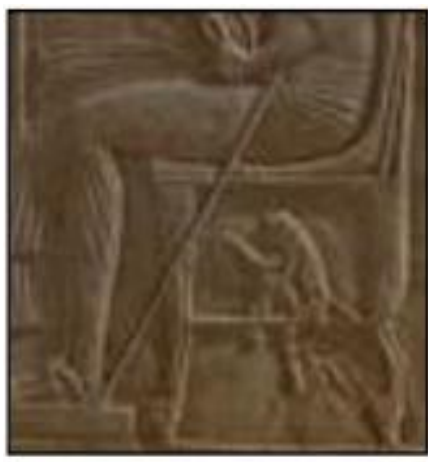

Fig. ^

A monkey under the chair of Ptahemwia in a joyful pose, Saqqara, N.K

after M.J. Raven, Jaarbericht Ex Oriente Lux « •, fig. ${ }^{\circ}$ (page $r \varepsilon$ ). 


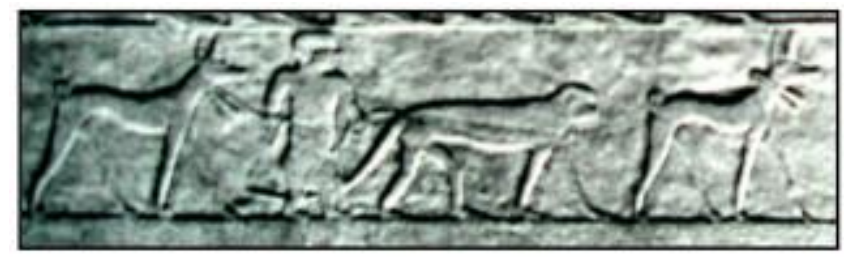

Fig. 9

A dwarf caretaker is leading two dogs and a vervet monkey at the tomb of Kagemni, Saqqara, O.K after W. Wreszinski, Atlas zur Altagyptischen, taf. $\Lambda_{6} 9$.

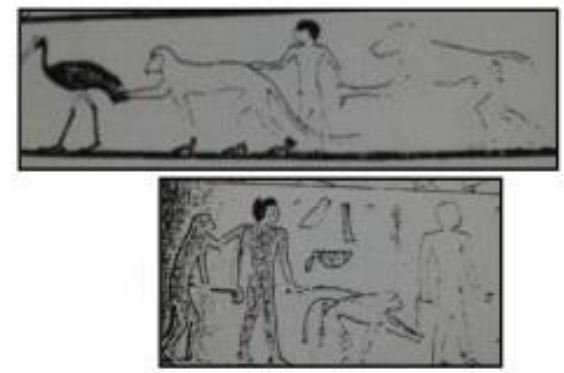

Fig. 1.

Two vervet monkeys with leashed playing with their two keepers, the other scene represents a monkey holding a boy from his hand and the boy is touching another monkey walking in front of him and the later monkey is touching a tail of an ibis bird walking in front of him, tomb of Nefer maet and Atet, Medum,O.K after Fl. Petrie, Meidum, pls. IV.। $\wedge_{6} r \varepsilon$ 


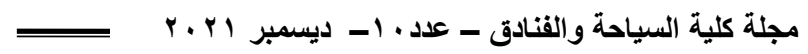

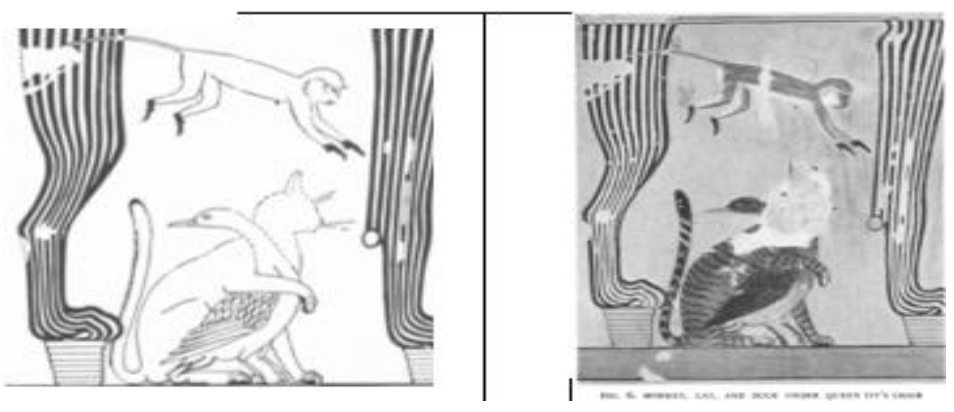

Fig. 11 ( $a$ and $b$ )

A monkey under the throne of king Amenhotep III and queen Tiy, jumping over a cat and a goose at a very lively movement

after N.De.G. Davies, The Metropolitan Museum, $\varepsilon r$.

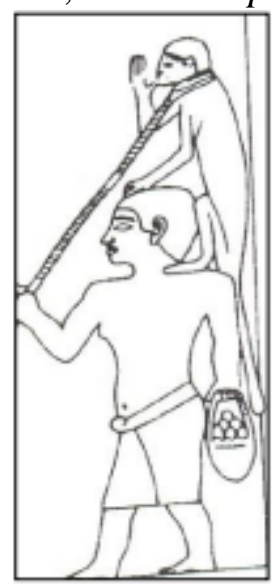

Fig. Ir

A dwarf caretaker is carrying a monkey over his head, tomb of Ankhmahour, Saqqara, O.K after N. Kanawati and A. Hassan, The Teti cemetery, pl. $\leqslant$ r. 


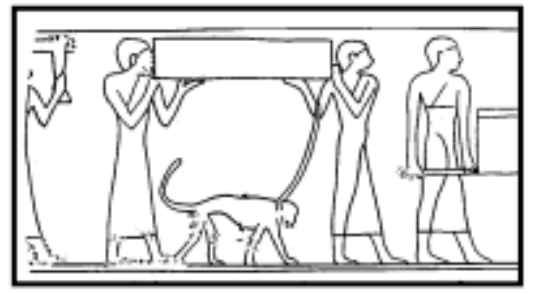

Fig. IT

A vervet monkey with a female servant who carries the funerary furniture of the queen. This scene is considered to be the only scene represents monkey with female attendant, tomb of Mersankh, Giza, O.K after W.S. Simpson, Mastabas, fig.^.

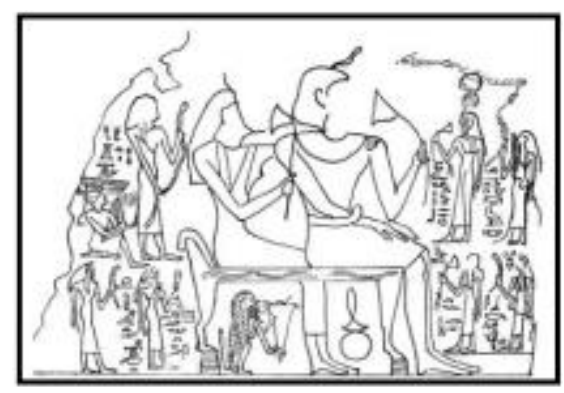

Fig. $1 \varepsilon$

A spotted monkey is under the chair of the owner of the tomb and his wife, tied with rope to the leg of the chair and it is holding a mdt vessel which contains a perfume ointment Tomb of Bebi, ${ }^{\text {th }}$ Dynasty, El-Kab after J.D. Vandier, Manuel D Archéologie. 


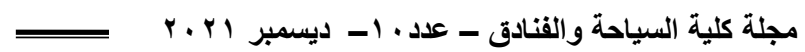

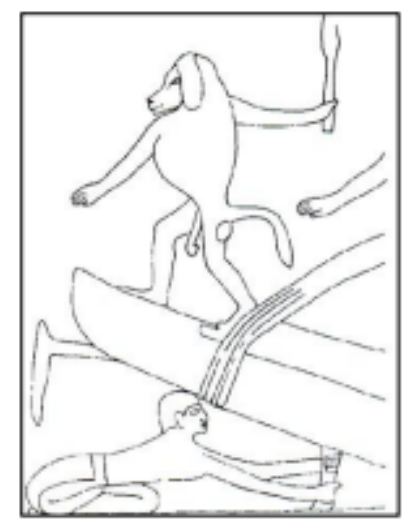

Fig. 10

A monkey is directing boat building while wielding a foreman's baton, tomb of Nfr-ka-hai, Saqqara O. K after L. Evans, Animal Behaviour, fig 9_ ) ₹.

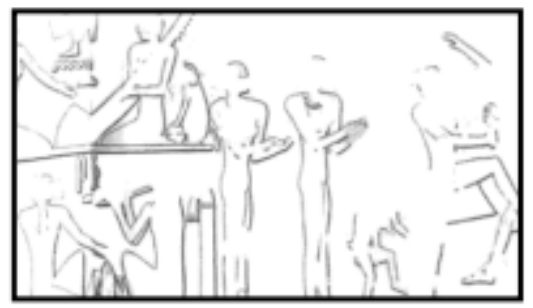

Fig. 17

A monkey is dancing behind a group of female dancers tomb of Serefeka at Sheikh Saied, O.K after N.de G. Davies, Shaikh Said, pl .iv. 
Classification of Monkey's Roles

— Relating to the Daily Life Scenes in Ancient Egypt

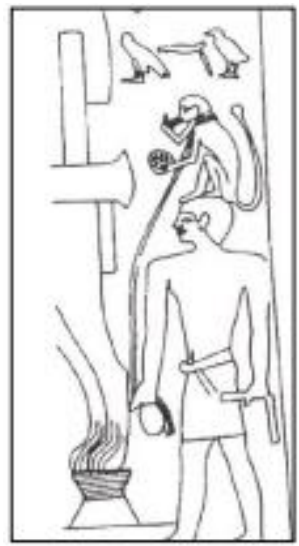

Fig. IV

A caretaker is carrying a monkey over his head and it is eating a kind of fruit from his hand,Saqqara, O.K after N. Kanawati \& M. Abd El-Raziq, tomb of Nikauisesi, pl.£^.

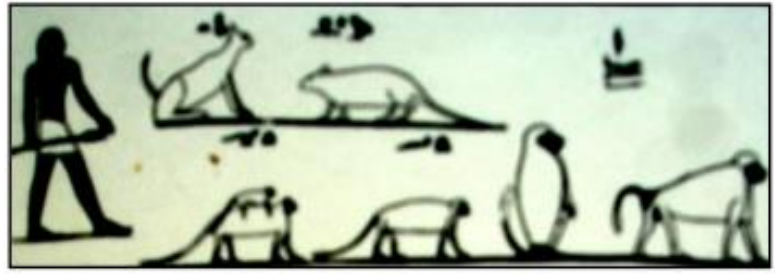

Fig. $1 \wedge$

Baboons and vervet monkeys among other animals as pets and the last one is a female monkey carrying its baby over its back, they are led by the keeper holding the usual stick with hands to control the animal behaviour, tomb of Baket III, Beni Hassan, M.K, after P. Newberry, Beni Hassan, pl. '. 

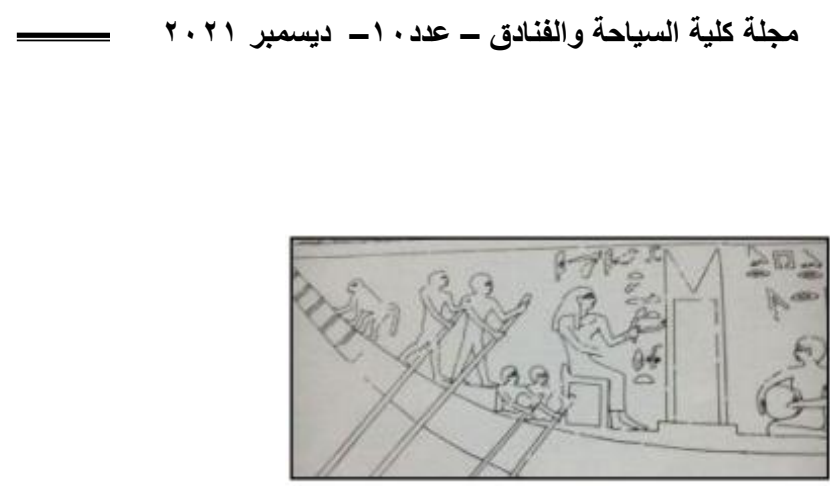

Fig. 19

Group of female Musicians at a bout with two monkeys at the two ends of the boat, Hamamya, O.K

After N. El Khouli \& n. Kanawati, The Old Kingdom Tombs, pl. ऍ \&\&々.

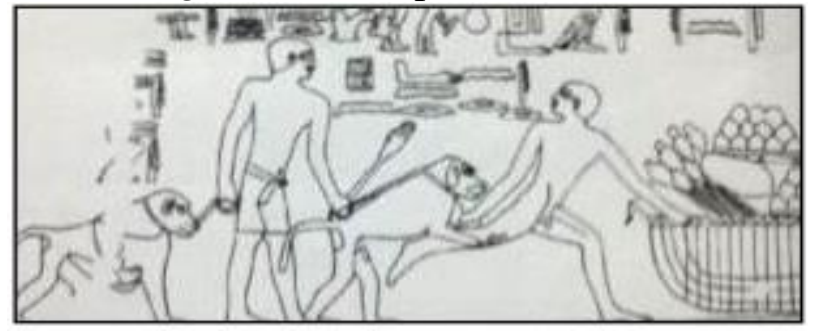

Fig. $r$.

Baboon policing at the market place and attacking a thief, on the left a female walks while clutching an infant to her chest, tomb of Tepemankh, Saqqara,O.K after L. Evanz, Animal Behaviour, fig. 'I- TV.

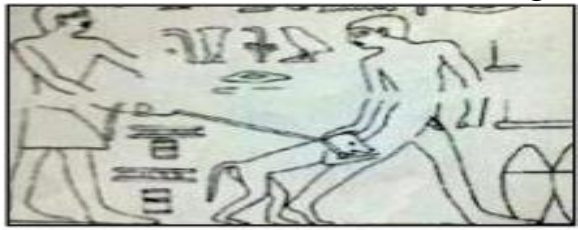

Fig. ${ }^{\prime}$

A leashed baboon attacks a young man and it has succeeded in biting the boy on his leg, tomb of Niankhkhnum-hetep, Saqqara, O.K after L. Evanz, Animal Behaviour, fig. 9-r . 


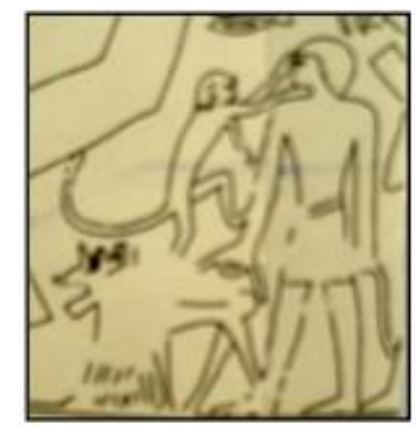

Fig. Yr

A vervet monkey jumping over the backs of two dogs and (attacks or plays) with the face of its Caretaker, Meir, O.K

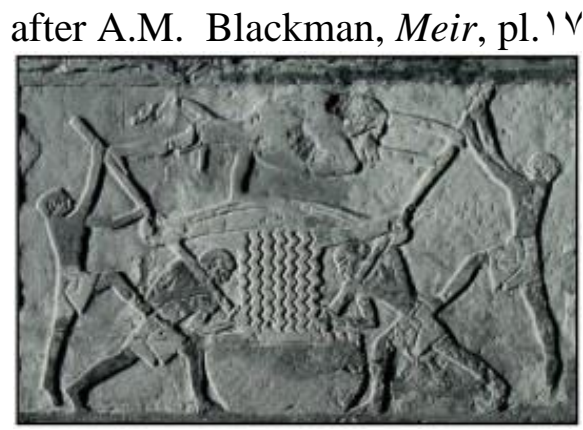

Fig. Yr

A baboon helping with the twisting of the must sack during the squeezing of grapes to make wine at the tomb of Nefer, Saqqara, O.K

After A. Moussa \& H. Altenmuller, The Tomb of Nefer and Kahay 


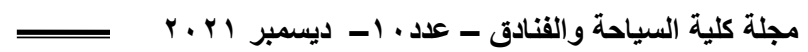

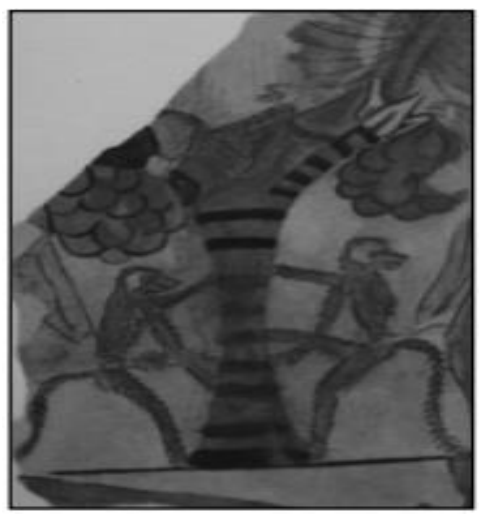

Fig. Y

Two green monkeys are climbing a dom-nut palm and they are tied with ropes. Ostraca at Deir el Madina, N.K.

after J. Vandier d'Abbadie, FIFAO Y, No. r... .

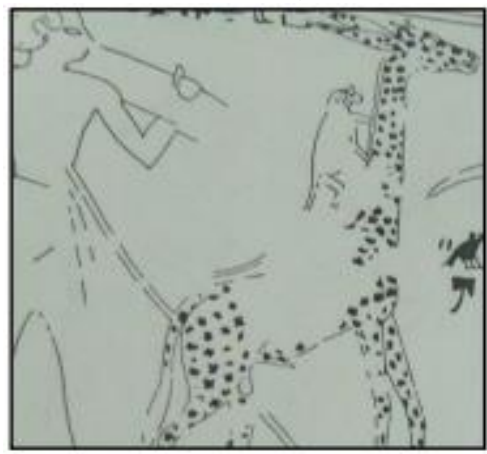

Fig. ro

A monkey over the back of a giraffe among a tribute scene which representing monkeys as a part of the gifts from the chief of the land of Punt to Amunedjeh, the owner of the tomb, Thebes, N.K after N.M. Davis, JEA $\uparrow \wedge$, pl.V. 
Classification of Monkey's Roles

— Relating to the Daily Life Scenes in Ancient Egypt

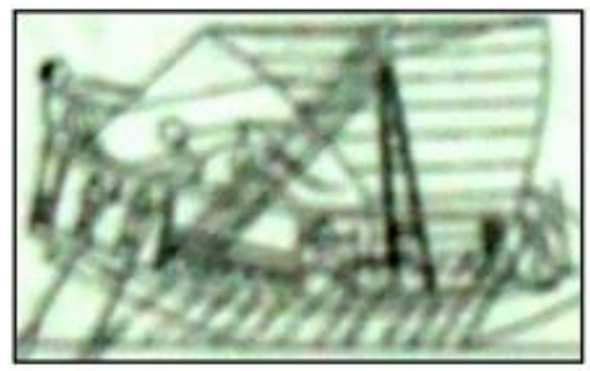

Fig. Y

A monkey climbing and moving freely at the mast of trading ship, tomb of snefruanymeret, O.K Sqqara after G. Jequier, BIFAO. ${ }^{9}$, pl.r.

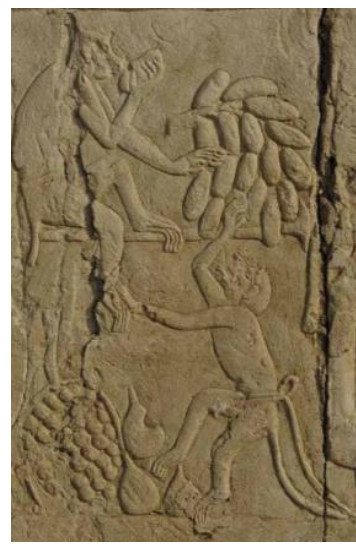

Fig. YV

two monkeys, tomb of Ptahemwia, Saqqara, N.K after M.J. Raven, R. van Walsem, B.G. Aston, L Horáckov, and N. Warner JEOL $\varepsilon \cdot$, ^r. fig. [1 1$]$ IA. 


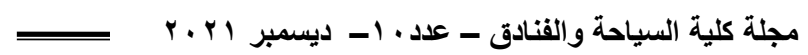

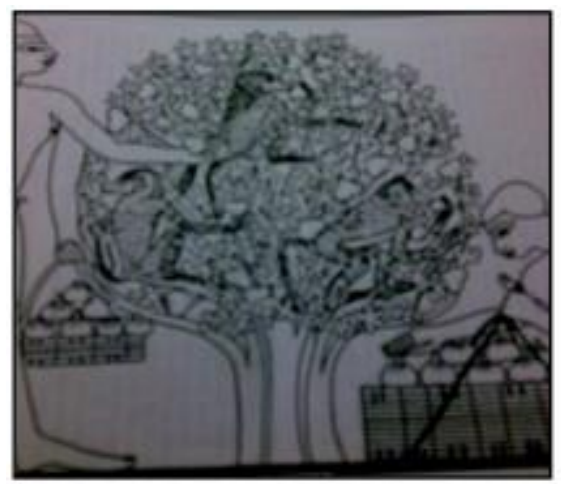

Fig. $\uparrow \wedge$

Three baboons on a fig tree eating figs and playing with each other, tomb of Khnumhotep, Beni Hassan, M.K.

after P.F. Houlihan, GM I ○ , fig. `.

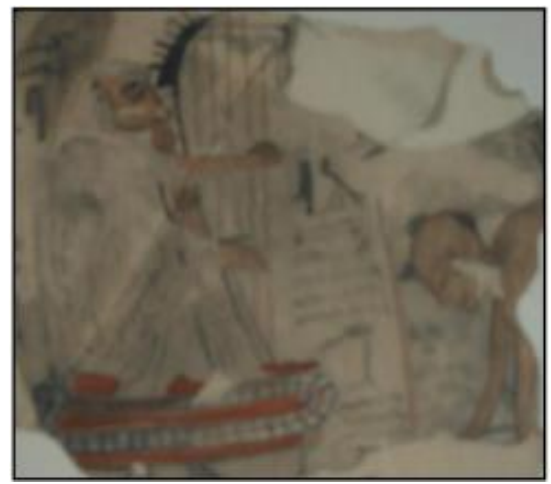

Fig. r

Ostraca of Deir el Madina representing a monkey playing at a harp ,N.K

after J. Vandier d'Abbadie, Catalogue des Ostraca, pl.xl, no. YrAl. 


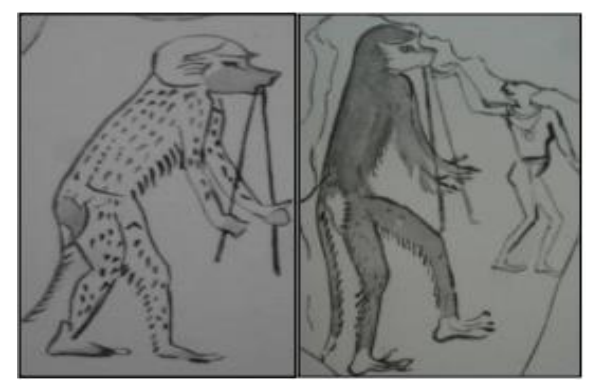

Fig. r.

Ostraca of Deir el Madina representing vervet monkey rehearsal for dancing with a boy and anther monkey dancing and playing on flute, N.K.

after J. Vandier d'Abbadie, FIFAO r, pl. CXVII, no. $Y \wedge \leqslant \tau, Y \wedge \leqslant 0$.

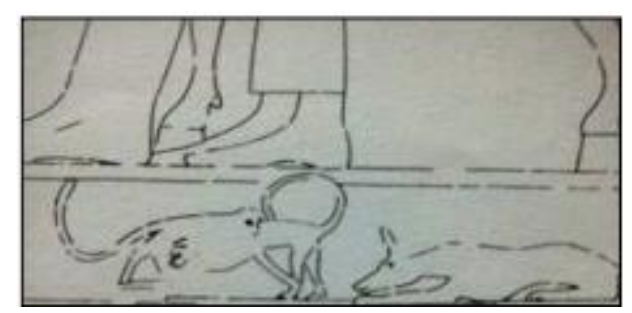

Fig. ${ }^{\top}$

Two playful monkeys in a very unique crossing pose and a dog under the seated figures of the owner of the tomb and his wife, tomb of Kai-khent, Hamammeya, after N. El Khouli \& N. Knawati, ACER r, pls. ${ }^{\mathrm{N} V}$ 
مجلة كلية السياحة والقنادق - عدد. 1- ديسمبر اYr م. 